\title{
Cárdenas y el reparto de los henequenales*
}

\author{
José Luis Sierra Villareal, José Antonio Paoli Bolio
}

\begin{abstract}
Il Estado mexicano ha tenido en el campesinado su más amplia e importante base de legitimación y ello se debe, en mucho, a la aplicación de la Reforma Agraria.

Al inicio de la tercera década de nuestro siglo, en medio de las severas condiciones que imponía la crisis económica internacional, el campesinado del país se movilizó urgiendo se cumplieran las promesas de la revolución. Para ese entonces la Reforma Agraria no habia alcanzado una concepción integral: casi se limitaba al reparto de los latifundios y a la asignación de los terrenos nacionales.
\end{abstract}

El presidente Cárdenas, con una vigorosa campaña de reparto y dotación de tierras, dio los primeros y mâs trascendentales pasos por la vía de la Reforma Agraria integral. Valiéndose de ella pudo restablecer el pacto histórico con el campesinado y desarmar los intentos de la restauración de privilegios que realizaban los terratenientes en alianza con nuevos y poderosos grupos. Es asi que la Reforma Agraria constituye un aspecto fundamental de lo que en la tradición política nacional se reconoce como "el cardenismo".

Yucatán ocupa un lugar privilegiado en la historia del agrarismo mexicano. Allí se escribió una de las páginas más gloriosas durante el régimen cardenista cuando se hizo realidad la vieja aspiración de Alvarado, de Carrillo Puerto y del Partido Socialista del Sureste (PSSE).

El 8 de agosto de 1937, tras muchos meses de disputas y escarceos, el presidente Cárdenas dio inicio al reparto de las haciendas henequeneras. No habian valido las ofertas y las negociaciones de los hacendados, el asesinato de lideres agraristas, las campañas de intimidación sostenidas durante años. La decisión del presidente Cárdenas frenaba la ofensiva de los hacendados henequeneros, apoyándose en las huestes que le habían dado vida al proyecto transformador del PSSE.

En este trabajo intentamos rescatar los momentos decisivos de tal periodo, refiriéndonos a sus protagonistas, a las fuerzas que se manifestaron, al comportamiento que asumieron. Nos parece el mejor homenaje que podemos hacer a cincuenta años de haberse cumplido en Yucatán el reparto de los henequenales.

\section{La situación que encontró el candidato a la presidencia en su visita a Yucatán}

El reparto agrario en Yucatán era una cuenta pendiente de cobro para el Estado surgido de la Revolución Mexicana. Durante el

* El material de este trabajo forma parte del libro "Cárdenas y el reparto de los henequenales", que aparecerá en fecha próxima. 
régimen del general Salvador Alvarado, en plena euforia constitucionalista, el general Venustiano Carranza habia tenido que prestar oídos a las quejas de los hacendados henequeneros, que se habian valido de sus relaciones en los Estados Unidos para demandar el inmediato cese del reparto de tierras que había iniciado el general Alvarado, de acuerdo con los postulados del constitucionalismo y la ley del 6 de enero de 1915.

Los distintos regímenes socialistas, entre 1918 y 1924, habían tenido como una de sus prioridades el reparto y la restitución de tierras. De 1921 a 1924, durante el interinato de Manuel Berzunza y los dos años que pudo cumplir Felipe Carrillo Puerto, en Yucatán se repartieron más de 600000 has de tierrras, quedando pendiente su resolución definitiva. Pero la gran mayoría de dichas tierras correspondía a terrenos nacionales, o bien consistian en tierras cuyas comunidades poseedoras carecian de documentación probatoria. Los gobiernos socialistas no sintieron las condiciones propicias para iniciar el reparto de las propiedades de los hacendados. Fue el propio Carrillo Puerto, en iniciativa aprobada los últimos días del mes de noviembre de 1923 y publicada el 11 de diciembre de ese año, el que tomó la decisión de repartir las haciendas abandonadas y los terrenos fuera de uso, catalogados como "tierras ociosas".

Al otrò día de publicado el decreto, el destacamento militar acantonado en la ciudad de Mérida se sumaría al levantamiento delahuertista, desconociendo al gobierno establecido. Felipe Carrillo Puerto iniciaría una huida que culminó con su fusilamiento veintidós dias depués, el 3 de enero de 1924.

La ofensiva de los hacendados yucatecos no era un hecho aislado, ni en el espacio ni en el tiempo. Desde la muerte de Felipe Carrillo Puerto los hacendados se habían impuesto la tarea de rehacer su poder de antaño, habiendo alcanzado en esos diez años muy buenos y abundantes logros. Su beligerancia respondía también al hecho de contar con el apoyo de distintas fuerzas del pais que pugnaban por la restauración de sus antiguos privilegios, y que se habian propuesto socavar las reformas cardenistas, en el mejor afán de hacer perder el rumbo a las reinvidicaciones sociales alcanzadas hasta entonces.

Desde su campaña como candidato a la presidencia de la República, Lázaro Cárdenas pudo constatar que las reformas promovidas por el general Alvarado y los consecutivos gobiernos socialistas de Yucatán, habian perdido su dinámica. El -otrora poderoso y hegemónico Partido Socialista habia caido en el juego del oportunismo político y las disputas facciosas habian terminado por hacerle perder el rumbo y la unidad de su esfuerzo.

Cárdenas también pudo darse cuenta de que los hacendados habian podido reconstituir su fuerza política y social, mellando la radicalidad de las reformas sociales, infiltrando las organizaciones populares a fin de agravar y aprovecharse de sus contradicciones, promoviendo el ascenso de los dirigentes que se identificaran con sus intereses. La hacienda henequenera habia mantenido su producción y aparecía como fuente de trabajo segura para más de

José Luis Sierra. "El Edo. Mexicano y las Diferencias Regionales: el Caso Yucateco", mimeografiado. 
cincuenta mil familias campesinas, a pesar de las dificiles condiciones que imponía la crisis de la economía mundial. Los hacendados habian hecho de la producción henequenera y de la influencia social de la hacienda su plataforma de despegue para reconquistar las instancias de poder perdidas, y había llegado el momento del encuentro con la cúspide gubernamental, buscando hacer valer sus intereses como los únicos y generales para el estado.

En las haciendas reinaba la más absoluta miseria entre los trabajadores, sujetos a una estricta subordinación que arrancaba con la práctica tradicional del "acasillamiento". Se calcula que a principios de los años 30 , había alrededor de sesenta mil campesinos henequeneros, la mitad de los cuales se consideraban abiertamente "peones acasillados".

La crisis de la economía mundial, si bien habia hecho impacto en los precios y en la demanda de la fibra, no resultó catastrófica para los hacendados henequeneros, toda vez que pudieron compensar la baja en sus ingresos por concepto de producción y venta de fibra, con los ingresos obtenidos por la manufactura de la misma. La industria cordelera en Yucatán se iniciaba por esos años, como resultado del reajuste en la división internacional del trabajo a que obligó la crisis del 29. Para ese entonces la difusión. de las cosechadoras combined -que cortan y desgranan a la vez, sin necesidad del hilo para engavillar- habia desplazado significativamente el uso de las antiguas máquinas engavilladoras, a tal grado que las grandes compañias productoras de maquinaria agrícola habían dejado de considerar-la fabricación de cordeles como renglón prioritario entre sus actividades y en sus intereses corporativos. La crisis de la economía agravó las condiciones para la industria cordelera en los Estados Unidos, cerrándose numerosas factorias. Los henequeneros yucatecos vieron la posibilidad de iniciarse en la elaboración de cordeles, como una forma de aumentar sus ganancias reteniendo el valor agregado por la elaboración de la fibra que ellos producian y que, tradicionalmente, se habian limitado a vender en rama.

La integración de la actividad manufacturera a las labores agrícolas de los henequeros fortaleció enormemente al grupo de los hacendados, pues además de los cuantiosos recursos económicos que les significaba, la cordelería les ofrecía nuevos y amplios márgenes de negociación para sus intereses, que no habian tenido a su disposición mientras se limitaron a la producción del campo. Así se manifestaria a corto plazo, durante los escarceos y negociaciones que rodearon al reparto agrario en Yucatán.

La muerte de Felipe Carrillo Puerto, además del alto costo que representó para la organización del Partido Socialista del Sureste, significó la pérdida de la autonomía que los consecutivos gobiernos socialistas habían logrado en su relación con las autoridades federales. El presidente Obregón no perdió la oportunidad de in= fluir en la esfera local al apoyar a José Maria Iturralde como gobernador sustituto, decisión contraria a la que había tomado la legislatura local, que estaba a favor del Lic. Miguel Cantón. Esta nueva relación de subordinación de la política local a los linea-

José Luis Sierra V.. "Hacia una Economía Politica de la Hacienda Henequenera", en Yucatán: Historia y Economia, núms. 17 y 20. 
mientos del centro tendria hondas e inmediatas repercusiones, toda vez que coincidia con el relevo presidencial, y el candidato seleccionado, general Plutarco Elías Calles, buscaba hacerse de contactos que le dieran un poder propio.

Los hacendados entendieron la situación, jugando a su favor el cambio de circunstancias. Tenían múltiples y distintas vías de acceso al general Calles, y le hicieron llegar noticias alarmantes sobre la situación yucateca y, en consecuencia, algunas ideas y propuestas que pudieran servirle a la hora de tomar decisiones en relación con Yucatán.

José Maria Iturralde tuvo que enfrentar una profunda división en el seno del Partido Socialista del Sureste, resistiendo la tenaz ofensiva que sostuvieron durante su corto mandato los partidarios de Miguel Cantón. Por otro lado, estuvo sujeto a un severo control del "centro", que le impedia tomar decisiones libremente y que veía con celo cualquier medida que tomara dirigida a consolidar su posición personal. Tal fue el caso de la orden que recibiera de abandonar la presidencia del Partido Socialista del Sureste, entregándosela a Bartolomé García Correa, de reconocida filiación callista. Con ello se divorciaba la fuerza de la gubernatura de la dirigencia socialista; asimismo se garantizaba la lealtad del Partido en cualquier circunstancia y en todo momento, incluyendo la sucesión gubernamental que se avecinaba. Como puede deducirse fácilmente, esta actitud de las autoridades centrales era alimentada por los informes de quienes veian en el gobernador Iturralde un obstáculo a sus intereses y que aceptaban su gobierno como un mero tránsito hacia una situación distinta, más favorable para ellos.

Las pugnas entre los dirigentes del Partido Socialista, la confusión de sus bases militantes y el desánimo que cundió en todos los niveles políticos, sirvió para que los hacendados continuaran su ofensiva, concretando sonados logros. En 1925, consiguieron que desapareciera la Comisión Exportadora del Henequén, que había sucedido a la Comisión Reguladora del Mercado del Henequén, y que controlaba la oferta de este producto yucateco en los Estados Unidos. Aprovechando su acercamiento al grupo obregonista, los hacendados lograron el reconocimiento de una empresa, Henequeneros de Yucatán, como la encargada de coordinar los distintos: sectores productivos -hacendados, comuneros y ejidatarios- y de resolver todo lo relacionado con la producción y la comercialización de la fibra. El gobierno federal aportaría recursos para apoyar la producción henequenera. El director de la cooperativa sería nombrado por el gobernador del estado. Como era de suponerse los hacendados tuvieron, desde el primer momento, el control de la empresa, contando con la posibilidad de negociar localmente sus intereses y con el apoyo federal anticipado. 4

El Dr. Alvaro Torre Díaz sucedió en la gubernatura a José María lturralde. Torre Díaz contaba con el apoyo del general Calles, ál que se habia acercado siendo secretario particular del general Salvador Alvarado. La selección de Torre Díaz constituyó un triunfo

\footnotetext{
3 Faulo Sánchez Novelo, "El Kanxoc: Ideología y Politica en el régimen de José Ma. Iturralde Traconis 1924-25”, Mérida, Ed. Maldonado, 1986.

t Ibidem.
} 
de los hacendados. Miembro fundador de la Liga de Acción Social -organismo fundado por un grupo de hacendados, inspirados en la doctrina social de León XIII-, fue también distinguido dirigente del Partido Nacional Católico. Activo y eficaz secretario particular de Salvador Alvarado, se ganó rápidamente la animadversión de los miembros más progresistas del equipo gobernante y, desde luego, de los líderes populares que propugnaban por más y más profundas reformas. Durante el gobierno de Castro Morales se vio precisado a abandonar Yucatán, reforzando sus relaciones en la ciudad de México. Perseguido por Felipe Carrillo Puerto y por toda la dirección del Partido Socialista del Sureste, tuvo que permanecer al margen de la vida política yucateca, siendo enviado como embajador al Brasil. Ocupaba ese cargo cuando fue postulado como candidato del Partido Socialista del Sureste a la gubernatura del estado.

En todo momento declaró que en su gobierno se hacía "más administración y menos política”. Y en efecto, dejó el control político del estado en manos de otro reconocido callista, Bartolomé García Correa, dedicando su tiempo a enriquecer sus relaciones con los hacendados. Protegió a los editores de El Diario de Yucatán, que seguian una linea beligerante, de defensa de los intereses de la oligarquía; Torre Diaz terminaria siendo accionista y colaborador de El Diario...

Con Torre Díaz recobraron su fuerza política todos aquellos miembros dirigentes del Partido Socialista del Sureste que habían sido rebasados por la dinámica del movimiento transformador: abogados y profesionistas, intelectuales, hacendados y comerciantes que habían respondido al llamado del general Alvarado y que, incluso, habían llegado a ocupar puestos de relevancia durante su gobierno o en los regimenes socialistas subsecuentes. ${ }^{5}$

Durante el gobierno del Dr. Torre Díaz se llevó a cabo el relevo en la dirigencia del Partido Socialista del Sureste, que ya se habia empezado a dar con las pugnas entre Iturralde y Miguel Cantón. A partir de entonces seria el grupo de "ilustrados", la camarilla de intelectuales y profesionistas, los que determinarian el rumbo de la organización partidista y, con ella, el rumbo de la política estatal. El reto que tenían que resolver los nuevos dirigentes políticos en el estado era cómo mantener la legitimidad social de la organización, cómo conservar el apoyo de las grandes mayorías. La personalidad y la fuerza política de Bartolomé García Correa aparecían como solución posible. El senador García Correa, presidente del Partido Socialista del Sureste, sucedería al Dr. Torre Diaz en la gubernatura del estado.

Bartolomé García Correa es, quizá, el mejor ejemplo del líder popular que llega a integrarse al aparato estatal, constituyéndose en "correa de transmisión", indispensable para el control político en una región dada. Militante del Partido Socialista del Sureste desde sus inicios, Bartolomé enfrentó la difícil tarea de consolidar la organización en la región que va desde Umán hasta Ticul en el sur, y en Maxcanú, Halachó y Opichén, al occidente y al

\footnotetext{
5 José Luis Sierra V., "El Carrillismo: Síntesis Progresista de Cinco Corrientes Contradictorias", conferencia sustentada en la Academia Yucatanense de Ciencias y Artes, mecanuscrito.
} 
norte, donde imperaban importantes caciques. Garcia Correa pudo desplazar a gentes como Loreto Baak y Mendoza, y subordinar a Sóstenes Carrillo y a los hermanos Euán, logrando mantener un estricto control político en esa importante zona del estado. Bartolomé Garcia Correa fundó su poder regional en el reparto de influencias, tráfico de aguardiente, protección a los juegos de azar, venta de patronazgos, permisos para fiestas, etc.. Popularmente conocido como "box pato" (pato negro), se constituyó en el lider indiscutido del Partido Socialista del Sureste desde el mandato de Torre Díaz, logrando disminuir con su férreo control personal las disputas personales que habian dividido y debilitado al Partido y que amenazaban con hacerlo desaparecer. Cercano colaborador del presidente Calles, formó parte del grupo constituyente del Partido Nacional Revolucionario en 1929, siendo nombrado secretario de Organización en la primera directiva. ${ }^{6}$

Pese a su personal arraigo popular, Bartolomé Gaŕcia Correa tuvo un comportamiento errático como gobernante: igual hacía la defensa más encendida de una causa popular que reprimía a cualquier contigente que hubiera escapado de su control o desatendido alguna indicación suya. Rápido e imaginativo en sus decisiones, autoritario en sus actitudes, tortuoso en sus gestiones, García Correa supo fincar su autoridad frente a la difícil situación derivada de la crisis económica del 29 , que habia tenido profundas repercusiones en Yucatán.

Bartolomé Garcia se valió de un grupo policiaco para ejercer un severo control político a lo largo y ancho del estado, al que mañosamente se denominó Defensa Revolucionaria. El humor negro del pueblo lo conoció como "la checa", parodiando la persecución policiaca del grupo yucateco con los fines represivos de la policía soviética.

Antonio Mediz Bolio y José Castillo Torre denunciaron en 1932 el carácter represivo de Defensa Revolucionaria:

... Consta aparentemente de 1500 hombres, distribuidos en todo el estado, que portan pistolas y rifles reglamentarios y que desfilan a tambor batiente por las calles y hacen honores al gobernador. Pero positivamente se trata de un grupo de 50 espias o 100 matones, especie de gavilla oficial de esbirros que espian, amagan y asesinan impunemente. Los demás son empleados públicos o miembros de las cooperativas, a quienes se obliga a esta clase de arbitrario servicio militar, con turnos, guardias y acuartelamientos aparatosos.?

"La Checa" fue muy temida y su acción más sangrienta fue perpetrada contra los campesinos de Opichén, al sur de Mérida, durante la cual se asesinó a 38 trabajadores del campo que resistían las imposiciones del gobernador.

"Box Pato" supo alternar con los grupos enriquecidos, estableciendo compromisos basados en el manejo de influencias y concesiones. Las actividades ilegales y las prácticas especulativas vivieron su "época de oro" durante el mandato de Garcia Correa, que también ofreció amplias garantías para el establecimiento de las primeras cordelerías, permitiendo la implantación de condiciones infimas de trabajo.

\footnotetext{
Ihidem.

' J. Castillo Torre, y A. Mediz Bolio, "La Agonia de Yucatán", Mérida, 1933, p. 8 y 9.
} 
"Box Pato" impuso al hijo del mayor magnate de las finanzas y agiotista del estado, Avelino Montes, al frente de la Cooperativa Henequeneros de Yucatán. Además de resultar inepto, era descendiente de una de las familias más odiadas por el Partido Socialista: la familia Montes Molina.

Algo aún más grave fue el decreto mediante el cual se fijaria el salario de los trabajadores en razón de los precios alcanzados por la fibra y de acuerdo con una tabla, publicada por la Liga Central del PSSE el 13 de agosto de $1933 .^{8}$

Personalista e irascible, tuvo frecuentes y numerosos conflictos con políticos, hacendados, miembros del clero y empleados de gobierno. Durante su mandato se efectuó el incendio del local que albergaba a El Diario de Yucatán, y que siempre se atribuyó a una orden suya, dadas la línea de permanente denuncia que habia asumido el periódico y la abierta antipatía contra sus editores que hacía saber, reiteradamente, el gobernador.

El estricto control político de que habia hecho gala durante su gestión cayó en un acelerado proceso de descomposición los últimos meses de su gobierno. Los abusos de poder, los escándálos por las componendas y las prácticas corruptas, y los conflictos con otros grupos y dirigentes políticos, acabaron por desgastar la popularidad del gobernante y la imagen de su administración.

La pérdida del control por parte del gobernador se manifestaria abiertamente durante el proceso de selección de quien debiera sucederlo en la gubernatura, una vez ratificada la candidatura por el Partido Socialista. Cinco posibles candidatos hicieron públicas sus aspiraciones. Se constituyó el Frente Reivindicador del PSSE con el afán de aglutinar a quienes se oponían al intento imposicionista de Garcia Correa. El Frente logró sumar el acuerdo de tres grupos en torno a la candidatura de José Castillo Torre, severo y pertinaz crítico de la persona y de la obra del gobernante. Gualberto Carrillo Puerto y César Alayola Barrera, sostuvieron sus aspiraciones a convertirse en los candidatos del socialismo.

Conviene señalar el grado de avance tenido por los intereses hacendatarios en el seno mismo del otro poderoso y radical Partido Socialista, ya que quienes representaban a las distintas facciones estaban altamente identificados con los intereses hacendatarios y, por ende, profundamente distanciados de cualquier proyecto popular. José Castillo Torre gozaba de amplias simpatías entre los hacendados. Su postura crítica hacia García Correa lo había llevado a identificarse con los editores de El Diario de Yucatân, que se habían convertido en los más feroces impugnadores de la obra gubernamental. Gualberto Carrillo Puerto trataba de capitalizar la magia que despertaba el apellido en su propio y único

\footnotetext{
" El "Gobierno Socialista de Yucatán" decretó, en agosto de 1933, la "Tarifa gradual para el pago de jornales en las fincas henequeneras del Estado", que establecia un ajuste al salario de acuerdo con las fluctuaciones del precio del henequén en el mercado internacional. Cabe señalar que al momento de acordarse el decreto se vivía una pronunciada baja en el precio de la fibra. En el articulo primero del mencionado decreto se puede leer que si el precio pagado en Progreso era de 25 cts. por kilo de fibra, el jornal minimo diario seria de 2 pesos, pero si el precio era de 10 cts. entonces el jornal se reduciria a 50 cts. Este documento se encuentra transcrito en Sigfried Askinasy, "El problema agrario de Yucatán"; Ed. Botas, 1936, p. 113.
} 
beneficio. Habia logrado concretar el apoyo de algunos grupos sumamente activos y contaba con el respaldo de importantes hacendados socialmente reconocidos por su participación en operaciones especulativas. Finalmente, el Lic. César Alayola Barrera aparecía como el representante del continuismo por haber sido parte del equipo de Garcia Correa y, de hecho, contaba con el apoyo irrestricto del gobernador saliente. Pero es necesario considerar que el apoyo dado por García Correa era, de suyo, una concesión al poderoso grupo de los hacendados, ya que Alayola era uno de los funcionarios más identificados y comprometidos con ellos; su candidatura fue vista como un intento de salvar la hegemonia del Partido Socialista, sin llegar a una ruptura con los intereses de los hacendados.

En síntesis, con cualquiera de los candidatos, los hacendados habrian visto avanzar sus intereses; no asi las ancestrales e incumplidas aspiraciones populares. La sucesión del 34 puso de manifiesto el alejamiento al que había llegado la dirección socialista de sus bases; tanto como se habian alejado del camino de las reivindicaciones populares y de los procedimientos democráticos. Si esto no hubiera sido percibido hasta entonces por los militantes del Partido Socialista, no quedó en duda una vez consumado el proceso de selección de su candidato a la gubernatura.

En una asamblea general, pública y abierta, como se había acostumbrado en el Partido Socialista tomar las decisiones trascendentales, fue promulgada la candidatura de José Castillo Torre, tras obtener una holgada mayoria sobre los otros aspirantes. Sin embargo, unos días después, se hizo pública la candidatura de Aloyola Barrera, argumentando fallas en el procedimiento de selección interna. Decisión tomada e impuesta por el gobernador, siguiendo las formas que ya se habian hecho costumbre.

La proliferación de disputas creaba un ambiente de conflicto permanente, aprovechado silenciosa y persistentemente por los hacendados para avanzar en sus logros, echando abajo, palmo a palmo, cada una de las reivindicaciones que hubiera alcanzado el movimiento popular entre 1915 y 1924. Los contingentes de trabajadores acasillados engrosaban día a día y los hacendados no tenían empacho en recurrir a ellos para enfrentar las demandas de los campesinos organizados en ejidos. Los acasillados se oponían a cualquier medida de reparto agrario, convencidos que atentaría contra su fuente de superviviencia.

La miseria de los trabajadores yucatecos había llegado a niveles tales en 1935, que narrarlos parece cosa de imaginerias desaforadas.

Para 1935-1936 el salario mínimo oficial fluctuaba entre $\$ 1.50$ y $\$ 3.00$, según la zona. ${ }^{10}$ Pero ganar ește salario era una ilusión que pocas veces se realizaba. Leemos en un informe que presentó Manuel Prieto, empleado de la Secretaría de Agricultura y Fomento, el 12 de marzo de 1936, sobre el municipio de Hunucmá, que muy pocas personas encontraban trabajo, y las que tenían la suerte de hallarlo sólo podían aspirar a un salario de .74 centavos. La mayoría de los trabajadores tenian que salir fuera. "Aquí el

\footnotetext{
9 "La labor negativa y obstruccionadora de Carlos R. Menéndez", Partido Socialista del Sureste, 1932. Reeditada por la Asociación de Economistas Revolucionarios de Yucatán en 1980.
}

${ }^{10}$ S. Askinasy, op. cit., p. 82. 
salario mínimo es una verdadera utopía". Explica que en el vecino pueblo de Tetiz pasaba lo mismo."

Siegfried Askinasy, en su libro "El Problema Agrario de Yucatán", presenta el resultado de sus estudios sobre la economía de los henequeneros, realizado en una de las haciendas que mejor pagaban a sus trabajadores por aquellos ànos de 1935 y 1936 . Expone el caso de la hacienda Sacapuc, del municipio de Motul. Según los cuestionarios que aplicó, la raya semanal oscilaba entre los 3.00 y los 8.00 pesos. Pero afirma que los 8.00 pesos, que se acercaban al salario mínimo de la zona, sólo los podian alcanzar contadísimos trabajadores que lograban obtener la gracia de trabajar toda la semana y contar con la ayuda de sus hijos en las labores. El salario medio de un cortador de pencas en Sacapuc, en julio de 1935 , era de $\$ 5.75$ por semana. Afirma el autor que en otras fincas era inferior para los acasillados y aún menor para los eventuales. $\mathrm{Y}$ este mísero salario se achicaba más por los altos precios de los alimentos en la región. Los comestibles se importaban de diversos estados de la República y de los Estados Unidos. Sólo de maiz se importaban 40 mil toneladas. $Y$ mientras este cereal se cotizaba en la ciudad de México a 7 centavos el kilo, su precio en Yucatán era de 13 y 14 centavos el kilo; el frijol se vendía en México a 8 centavos y en Yucatán a 19 centavos el kilo; el arroz de segunda clase podía comprarse a 40 centavos en el campo henequenero, mientras en la capital de la República costaba 16.5 centavos. ${ }^{12}$

Como usufructuarios por años de la miseria social, los hacendados estaban conscientes que la situación era insostenible y que se hacian necesarios cambios profundos. El reparto agrario era una demanda generalizada en el país que debía atenderse de manera impostergable, si no se quería perder la incipiente tranquilidad alcanzada. Los hacendados sabían que no podían evitar el reparto agrario, pero estaban decididos a negociar los plazos y los términos del mismo. Eran conocedores de su fuerza y de las limitaciones en las que habian caído las demandas y las organizaciones populares. Se habian acostumbrado al lenguaje radical y habian terminado por perder el miedo a las masas movilizadas. Más aún, habian aprendido a valerse del uno y de las otras para avanzar en sus objetivos y para desgastar a quienes se les opusieran.

Tan pronto se incluyó la realización del reparto agrario como un objetivo del Plan Sexenal 1934-1940, elaborado por el Partido Nacional Revolucionario, el grupo de hacendados constituyó la Asociáción de Defensa de la Industria Henequenera (ADIH), a fin de establecer una estrategia y de orquestar los esfuerzos y las iniciativas de quienes se identificaran con sus intereses o pudieran servir a su causa. La ADIH, como se demostraría en breve tiempo, no renunciaba a recurso alguno: atendía, eficaz y permanentemente, las instancias legales; sostenía una amplia y costosa campaña informativa, tendiente a conformar una opinión favorable a su causa; movilizaba contigentes numerosísimos de peones y gente de campo; mantenía estrechas relaciones con organizaciones políticas de todo tinte, local y nacionalmente; alimentaba los contactos con funcionarios públicos de alto nivel y con representantes de hacen-

"Archivo General del Estado (AGE) Comisión Agraria Mixta, 1936, caja 4.

I2 S. Askinasy, op. cit. p. 31 . 
dados de otras regiones del país, etcétera.

Localmente la ADIH cobró una fuerte presencia. Su asesor jurídico, Enrique Aznar Mendoza era, a su vez, el representante legal del sindicato ferrocarrilero y del Frente Unico de Trabajadores del Volante, dos de las más importantes y más radicales agrupaciones obreras del estado.

Los hacendados movilizaron a sus peones acasillados manipulando sus creencias religiosas y sus necesidades materiales en contra del comunismo y de la reforma agraria, "que les quitarían a sus hijos y las tierras en que trabajan". No era nuevo que laş masas acasilladas fueran utilizadas por los hacendados para defender sus intereses; ni fue dificil hacerles sentir que los ejidatarios buscaban despojarlos de sus trabajos, familias y bienes.

Las distintas organizaciones anarquistas, muchas de las cuales integraban la Confederación General de Trabajadores que jefaturaba Porfirio Pallares, sirvieron también a la causa de los hacendados. La CGT yucateca seguia los lineamientos de los anarquistas nacionales, que habian hecho del Partido Comunista y de su estrategia los enemigos a vencer en "el seno de la clase obrera". Para el anarquismo, el reparto agrario llevaba al "aburguesamiento" del campesinado, convirtiéndolo en apoyo corporativo del Estado, promotor y beneficiario del reparto. En estos supuestos la CGT coincidía con los afanes oposicionistas de los hacendados y trataba de aumentar su fuerza política, valiéndose del espacio que le. brindaban los hacendados y las organizaciones empresariales.

Con este respaldo, la CGT pudo destacar rápidamente, aumentando el número de sindicatos afiliados y de contingentes campesinos integrados a su estrategia. Su línea política iba a tono con su lenguaje beligerante, dedicando buena parte de su capacidad y recursos a combatir el avance de las organizaciones populares y a denunciar a sus dirigentes.

Cárdenas conoció en detalle la situación prevaleciente en Yucatán durante su campaña como candidato a la Presidencia. Sin duda alguna, fue entonces cuando se decidió a establecer una estrategia a fin de poder cumplir con el reparto de los henequenales.

El equipo de analistas del general Cárdenas y el propio candidato pudieron evaluar el trabajo que realizaban distintas organizaciones políticas de carácter popular, en contraposición con los intereses y los esfuerzos de los hacendados. Las bases obreras y campesinas del Partido Socialista, aglutinadas para ese entonces en torno a las siglas de la Confederación de Ligas Gremiales de Obreros y Campesinos "Partido Socialista del Sureste" (CLGOC), habian logrado conservar su unidad orgánica, al margen de las divisiones en la cúpula y de las disputas facciosas de sus dirigentes. Sin llegar a tener la fuerza de antaño, al paso de los años habian ido destacando líderes campesinos en las distintas localidades, que encontraban apoyo en la actividad permanente y responsable de algunos dirigentes estatales, conscientes de la importancia del trabajo político en las bases. Tal fue el caso de Rogerio Chalé, un joven campesino originario de Telchac, que supo ganarse el reconocimiento en todo el estado a partir de su labor dirigente en el área central de la zona henequenera. Sería asesinado al convertirse en el líder indiscutible del campesinado, apenas unos meses antes de efectuarse el reparto agrario. 
Por otro lado, existia un enorme potencial político en una serie de grupos que se negaban a aceptar la línea colaboracionista con los hacendados que habia sido asumida por la cúpula de la dirigencia socialista. Profesionistas, maestros, estudiantes, lideres obreros y gremiales, conformaban una amplia corriente de opinión radical que, desde luego, estaba a favor del reparto agrario y. de la afectación de los intereses hacendatarios.

El Partido Comunista Mexicano había establecido recientemente una filial en Yucatán, aprovechando el trabajo que realizaban algunos estudiantes pertenecientes al grupo ORDEN y a la labor que habia estado desempeñando el dirigente panadero Diego Mongiote Rosado entre numerosos sindicatos y grupos gremiales de la capital y del interior del estado. El PCM en Yucatán publicaba un órgano periodístico con el título "El Marxista"."13

Un grupo de militantes del PCM sumaria sus esfuerzos con distintos dirigentes sindicales para fundar en 1934 la Federación Sindical Independiente (FSI). En ese entonces la Federación representaba a un grupo muy reducido de trabajadores, pero aprovechaba. las inquietudes existentes en los distintos sectores laborales y los. márgenes de acción que se le permitian para realizar un trabajo permanente de agitación y afiliación del que ya empezaba a recoger los primeros y notables resultados.

El general Cárdenas entendió que para realizar el reparto agrario era necesario desinflar la ofensiva de los hacendados, lo que hacía indispensable contar con una fuerza popular de importancia considerable, que los enfrentara, como una forma de nulificar sus presiones. La dirigencia de la FSI habia dado muestras de tener capacidad suficiente para encabezar dicha corriente, ya que había trabajado con las bases y los grupos más radicalizados de la Confederación de Ligas Gremiales, dependiente del PNR, sin entrar en conflicto con su dirigencia y manteniendo respetuosas relaciones con el gobernador Alayola.

Con la sola simpatía del general Cárdenas y el apoyo que podían lograr entre los funcionarios del gobierno federal y estatal, el trabajo de la FSI magnificó sus resultados, aumentando aceleradamente el número de organizaciones afiliadas en todo el estado. La severa reducción de los salarios que significó la aplicación de la "Tarifa Gradual...", acrecentó el descontento popular en esos años e hizo que aun los trabajadores acasillados de las haciendas respondieran a la movilización en demanda de aumento de salarios. La FSI y la CLGOC ampliaron su influencia entre los trabajadores acasillados, violentando el tradicional control que sobre ellos habian mantenido los hacendados y que buscaban mantener con la colaboración de la CGT. Las huelgas obreras aumentaron en número y beligerancia, contagiando a los trabajadores del campo. La Procuraduría del Trabajo, dependencia del gobierno estatal encargada de los laudos laborales, otorgaba la razón a las demandas. obreras y promovía los emplazamientos del peonaje acasillado en demanda del cumplimiento del salario mínimo. La solidaridad de los trabajadores impedía que hubiera lucha pequena y hacía crecer cualquier manifestación de descontento contra los hacendados.

${ }^{13}$ A. Betancourt Pérez, "La Federación Sindical Independiente", Mérida, 1979; p. 11 . 
Y así como hubo un clima favorable a las demandas de los trabajadores en los distintos tribunales laborales, también hubo un cambio sustancial en el control político del estado al designarse como comandante militar a alguien que se había distinguido por sus dotes negociadoras y que guardaba una personal afinidad con los movimientos y los intereses populares, el general Rafael Cházaro Pérez.

Hemos dicho que el general Cárdenas conocia la situación en Yucatán y en el resto del país. Sabía que la reforma agraria era una medida indispensable para fincar la rectoría estatal sobre bases sólidas. Estaba convencido de que la reforma agraria ayudaría a redefinir los espacios de participación de los distintos sectores sociales. Cierto, la reforma agraria tenia un profundo sentido económico. Pero en ese momento cobraba preponderancia su sentido político. Con la realización del reparto agrario se desmantelaria la ofensiva que encabezaba el sector más retardatario de la burguesia y se lograría organizar al campesinado como reserva política del Estado y de su legitimidad social.

En Yucatán, el reparțo afectaria los intereses de un sector que había logrado mantener su hegemonía sobre el conjunto de la sociedad durante casi un siglo, golpeándolo precisamente en el factor que había sido la clave de su dominio: la subordinación de la población. Los afanes de transformación que habían impulsado la acción de los distintos gobiernos revolucionarios se habian topado con la fuerza irreductible de los hacendados y de sus propiedades.

El campesinado yucateco había llegado a concederle un valor mítico a la propiedad del hacendado y a su fuerza política. El reparto de las haciendas aparecía como una aspiración legendaria. El campesino henequenero era testigo de las enormes riquezas que se constituían con su trabajo y le parecía un sueño que llegaran a ser suyas al efectuarse el repartimiento de las tierras, más todavía, cuando los anuncios del reparto iban acompañados de promesas de créditos y recursos de apoyo.

Este fue el Yucatán que conoció Cárdenas y en el que decidió realizar el reparto agrario. Los contendientes se conocian, eran los mismos, eran legendarios; Cárdenas, una vez más habia optado por el pueblo. La suerte estaba echada.

\section{Primeros escarceos: la caída de dos gobernadores}

El primer año de gobierno del Lic. César Alayola Barrera coińncidió con la campaña presidencial del general Lázaro Cárdenas. Durante su gira por Yucatán, Cárdenas dejó claramente definida su voluntad de cumplir con el reparto agrario que postulaba el Plan Sexenal 1934-1940. En varias entrevistas e intervenciones públicas sostuvo la necesidad de cumplir con la repartición de tierras en la zona henequenera. A partir de ese momento, los hacendados hicieron públicos sus esfuerzos por oponerse a lo que ellos consideraban "la desintegración de la riqueza henequenera"."

1t Gustavo Molina Font, "El Problema Agrario en la Zona Henequenera de Yucatán", México, julio de 1934; Alberto García Cantón, "Memorias de un ex-hacendado henequenero", Mérida, Imp. Diaz Massa, s/f.; Gustavo Molina Font, "La Tragedia de. Yucatán", México, Ed. Jus, 1941. 
Los consejeros y asesores del presidente pudieron darse cuenta de que el gobernador del estado no tenía el control de las distintas fuerzas políticas y de que la dirigencia formal de la Confederación de Ligas Gremiales tampoco garantizaba la conducción de un movimiento masivo. Fue así como el régimen cardenista tuvo que buscar entre los distintos agrupamientos y organizaciones a fin de. valerse de aquéllos que pudieran resultar valiosos en una estrategia de apoyo al reparto agrario, enfrentando las presiones y los contingentes movilizados por los hacendados.

Durante todo el año de 1934, antes de que el general Cárdenas tomara posesión de la presidencia de la República, hubo un enfrentamiento sordo, continuo, entre las organizaciones populares y aquéllas que respondían a los intereses de los hacendados. Podemos decir que a lo largo de este año hubo una decantación de intereses y fuerzas. Por un lado los hacendados, movilizados en turno a la Asociación de Defensa de la Industria Henequenera (ADIH) apoyándose en las agrupaciones obreras de corte anarquista integradas a la CGT que dirigía Porfirio Pallares, y en los sindicatos de Ferrocarrileros y de Trabajadores del Volante, que manejaba el licenciado Enrique Aznar Mendoza como asesor legal. Frente a ellos ganaba adeptos y fuerza política la Federación Sindical Independiente, que aglutinaba a los núcleos más activos de la Confederación de Ligas Gremiales y a los grupos de reciente integración del Partido Comunista Mexicano. La FSI sería la base en Yucatán del Comité de Defensa Proletaria, que se formó en todo el país como apoyo al presidente Cárdenas y de donde surgiria la Confederación de Trabajadores de México (CTM), casi dos años después.

Se multiplicaron las huelgas y los conflictos laborales en la ciudad y en el campo: El enfrentamiento asumia lenguaje beligerante en los distintos diarios, en las hojas volantes y en los mítines. El gobernador Alayola se mostraba incapaz de evitar la situación, ni siquiera de influir de alguna manera para atemperarla. Era evidente que el desarrollo de los acontecimientos políticos no pasaba por el palacio del gobernador, ni tenía a la oficialista Confederación de Ligas Gremiales por eje.

Ambos bandos trataban de ganarse el favor de las autoridades con el ánimo de acumular fuerzas y mejorar posiciones. El jefe. militar y el gobernador del estado estuvieron sujetos a incesantes y crecientes presiones, de una y otra parte. La ideología y la línea política del gobernador Alayola se acercaba más hacia los intereses de los hacendados, con una clara y profunda salvedad: el reparto de las tierras. Alayola daría reiteradas muestras de su compromiso con el campesinado en materia de tierras, lo que le valdría frecuentes choques con los hacendados y seria uno de los motivos de mayor peso en su caída, como veremos más adelante.

Tan pronto Cárdenas tomó posesión del cargo presidencial, en diciembre de 1934, los acontecimientos políticos se desbordaron en Yucatán, lanzándose los distintos bandos en abierta ofensiva. Los hacendados suspendieron la contratación de trabajadores eventuales y empezaron a reducir el número de peones acasillados en sus haciendas. Se multiplicaban las demandas laborales y crecía el descontento y el tono de las exigencias sindicales. Siguiendo adelante con su estrategia, los hacendados se negaron a desfibrar 
las hojas de henequén de los ejidos y de los planteles comunales; cada día eran más las plantas desfibradoras paradas y crecia el número de las haciendas abandonadas. Los campesinos organizados demandaban la entrega de las desfibradoras y la realización inmediata del reparto de los henequenales. Los hacendados argumentaban falta de garantías para continuar laborando y exigian medidas definitivas al gobierno del Estado.

El 15 de mayo de 1935, los ejidatarios de Cacalchén se posesionaron de la planta desfibradora de la hacienda Puhá, pese al grave riesgo que suponía. Escopetas en mano vigilaron la primera raspa ejidal, y la reacción de los hacendados no se hizo esperar. En pocos dias se paralizaron las tareas de desfibración en todo el estado y así continuarian "hasta que no se castigue a los ejidatarios aventureros de Cacalchén". 15

Contra lo que demandaban y pudieran esperar los hacendados, el Congreso del Estado legalizaba el 27 de mayo la ocupación temporal de los equipos de desfibración de las haciendas al promulgar la Ley de Arrendamiento Obligatorio de los Equipos para la Elaboración del Henequén. El gobernador Alayola avalaría e impulsaría la aplicación de este decreto. Sus días al frente del gobierno estatal estaban contados. Perdido el apoyo circunstancial de los hacendados, Alayola quedaba completamente al garete; para nadie era necesario, para muchos era un estorbo.

En ese entonces se habian hecho públicas las pugnas del presidente Cárdenas con su antecesor y se había desatado la persecusión de los callistas que hubieran ocupado puestos políticos en cualquier nivel. El licenciado César Alayola tenía bien ganada reputación de callista, recibiendo también por ese motivo sonados y reiterados ataques.

El general Francisco Múgica, secretario de Comunicaciones, vio la oportunidad de hacerse del control de los Ferrocarriles Unidos de Yucatán, moviéndole el tapete a un gobernador callista. Los trabajadores ferrocarrileros habían sido un gremio tradicionalmente combativo y vieron en la conflictiva situación reinante una excelente oportunidad de sacar provecho. Pronto organizaron un movimiento en demanda de mejores sueldos y de mayores prestaciones. El gobernador Alayola, responsable último de la empresa estatal, respondió que el erario carecía de medios para afrontar la demanda de los trabajadores. El general Múgica formuló un plan de reorganización administrativa, para lo cual proponía "...cambio del actual Consejo, ingerencia del sindicato en la dirección de la empresa y ayuda financiera del gobierno nacional". 16

El general Múgica trataba de hacerse del control de la empresa y de ganar el apoyo del movimiento ferrocarrilero. El gobernador Alayola no podía aceptar la pérdida de una importante fuente de poder y de influencia en la vida del estado. El movimiento ferrocarrilero aumentó sus exigencias y logró un apoyo generalizado en la población. La FSI, comprometida con el cardenismo en su lucha contra Calles, también apoyó al movimiento de los ferrocarrileros.

La dirección de los hacendados, constituida a partir de la Asociación Defensora de la Industria Henequenera, respaldó al movi-

${ }^{15}$ El Diario de Yucatán y El Diario del Sureste, del 16 al 28 de mayo de 1935.

16 El Diario de Yucatán, 7 de sept. de 1935. 
miento ferrocarrilero. Los hacendados tenian urgencia de colocar en la gubernatura a gente que les fuera incondicional para evitar, contra toda las presiones del centro, el reparto agrario. El río revuelto era para ellos necesario.

Por eso El Diario de Yucatân, órgano de prensa de las elites hacendatarias, apoyó a los ferrocarrileros contra el gobernador. $E l$ Diario del Sureste, órgano de prensa del gobierno, respaldaba al gobernador Alayola.

En esta ocasión, los sindicatos blancos, comandados de manera destacada por la CGT, marcharon junto con los miembros de la FSI. También los contingentes antiagraristas, formados por los acasillados de las haciendas, marchaban por las calles de Mérida junto con los sindicatos rojos de la FSI.

En El Diario de Yucatán, en su edición del 13 de septiembre de 1935, apareció un desplegado de los trabajadores del riel, donde informaban que habian votado por la huelga:

...la mayoría de los ferrocarrileros votan por la huelga. El comité del Sindicato Ferrocarrilero Peninsular ha recibido hasta el dia de hoy los siguientes votos de la huelga. Estos votos representan más de la mayoría para emplazarla. Hacemos constar que estos votos fueron dados por los socios de manera voluntaria a pesar de la presión ejercida por la Empresa, quien comisionó a empleados serviles para amenazar con el cese si daban su voto afirmativo.

La empresa hizo publicar desplegados al dia siguiente, donde desmentía la afirmación de que presionó a los trabajadores para que decidieran contra esta "injusta huelga", y que "es el Comité Ejecutivo del Sindicato el que ha venido agitando a los trabajadores y presionándolos con amenazas de aplicarles la cláusula de exclusión si no votaban por la huelga"."

Las mutuas acusaciones no cesaron. El 15 de septiembre, El Diario de Yucatán, dio a conocer una carta dirigida al presidente Cárdenas, en la que diversas organizaciones de trabajadores, incluida la FSI protestaban enérgicamente "por la forma reprobable que el Gobierno del Estado, como principal accionista de la Empresa presiona a los obreros, no obstante estar convencidos que la inmensa mayoría de los ferrocarrileros votaron por la huelga". ${ }^{18}$

Los ferrocarrileros exigian que se les pagara puntualmente, que se les concedieran 15 días de vacaciones al año, que se cumpliera con el descanso obligatorio en los días festivos o se les pagara como tiempo extra, reinstalación de los trabajadores despedidos injustamente y otras peticiones de carácter gremial. Solicitaban también que el Consejo de Administración de la compañia se integrara con representantes de los trabajadores libremente elegidos. ${ }^{19}$

El 22 de septiembre, el Sindicato de Cordeleros de Yucatán votó la huelga en apoyo a los ferrocarrileros. ${ }^{20}$

El 24 de septiembre, en la primera plana de $\mathrm{El}$ Diario del Sureste, "El Gobierno Socialista del Estado de Yucatán... Convoca a todos los grupos del Sindicato Ferrocarrilero Peninsular para que

${ }^{17}$ El Diario del Sureste, 14 de sept. de 1935.

$1 \%$ El Diario de Yucatán, 15 de sept. de 1935.

is El Diario de Yucalán, 23 de sept. de 1935.

21 Ibidem. 
se reúnan en el despacho del suscrito gobernador del Estado". Firman este llamado el gobernador Alayola y el secretario de Gobierno Fernando López Cárdenas. ${ }^{21}$

Al día siguiente, los trabajadores del riel respondieron que no aceptaban; y lo hicieron en las páginas de El Diario de Yucatán. En esa misma edición se informaba que la CGT habia decidido secundar la huelga decretada por el Sindicato Ferrocarrilero Peninsular. También se informaba que el Comité de Defensa Proletaria habia acordado apoyar el movimiento, respaldándolo "con todas las agrupaciones que controla, las cuales representan a más de 200 mil obreros". 22

El 6 de octubre, El Diario del Sureste informó que "el Congreso del Estado designó el día de ayer al Lic. Fernando López Cárdenas, en sustitución del Gobernador César Alayola Barrera, que solicitó licencia indefinida".

El candidato de los hacendados dirigidos por la ADIH no logró colocarse. El presidente Cärdenas, apoyado en el Jefe de la Zona Militar, general Rafael Cházaro Pérez, en el Comité de Defensa Proletaria y en la mayoría de los miembros del Congreso del Estado, respaldó a un personaje que le garantizara que el reparto agrario se llevara a cabo, al mismo tiempo que se aseguraba al gobierno de Yucatán como aliado contra los embates de la elite callista. El nuevo gobernador López Cárdenas renunciaría a sus vínculos con el callismo y se apoyaría en los mismos elementos que lo promovieron. Y de manera destacada, se apoyaría en la FSI y en sus intelectuales, miembros del PCM. También encontraría un fuerte respaldo en Cházaro Pérez, que simpatizaba también con la FSI y en diversas ocasiones apoyó abiertamente sus movimientos.

El apoyo de los trabajadores me dio no poca fuerza cerca del general Cházaro Pérez -explica el maestro de Kinchil, que colaboraba con la FSI-. Logré que se exigiera a las autoridades de Kinchil la aplicación de los salarios mínimos, y se impuso lo mismo a los propietarios de las haciendas. ${ }^{23}$

La reacción de los hacendados de la ADIH no se hizo esperar. Había fracasado su plan de asegurarse el control de la gubernatura a la caída de Alayola. Sabían que López Cárdenas no podía ser gente cercana a sus intereses. Que las fuerzas obreras y campesinas tenderian a radicalizar sus demandas y sus acciones. Sabian también que el apoyo político y militar del centro era para el nuevo gobernador que se pronunciaba radicalmente favorable al cumplimiento de los mandatos del artículo 27 constitucional.

A los hacendados les convenía hacer que la agitación continuara. Las pasiones estaban desbordadas; los movimientos estudiantiles, obreros y campesinos eran masivos y podian ocasionar la caida del nuevo gobernador.

El 8 de octubre de 1935 se solucionaba la huelga de ferrocarriles al entregar al sindicato la administración de la empresá.

Pero el 11 del mismo mes, Porfirio Pallares, dirigente de la CGT,

21 El Diario del Sureste, 24 de sept. de 1935.

22 El Diario de Yucatán, 25 de sept. de 1935.

${ }^{23}$ Entrevista al Prof. Antonio Betancourt Pérez, Revista Tiempo, 21 de dic. de 1980. 
afamado por su trayectoria de formador de sindicatos blancos al servicio de los hacendados, envió un telegrama a todos los presidentes municipales, en el que se señalaba:

Trabajadores, gritó que viva el General Lázaro Cárdenas, viva el General Cházaro Pérez, viva el Ingeniero Alfredo J. Pérez, derrocó gobierno del Estado. Urge identificación movimiento trabajadores organizados. Atentamente. Porfirio Pallares. Federación General de Trabajadores. $^{24}$

El telegrama no se difundió por el telégrafo oficial, pero sí se transmitió por el telégrafo de los ferrocarriles. El mismo día 11 se organizó una manifestación convocada por la Federación Regional de Obreros y Campesinos y por la Federación General de Trabajadores, de la CGT, dirigida por Pallares.

Diversos miembros de la FSI, acostumbrados a marchar en los dias pasados con estas federaciones, se sumaron a sus contingentes. El nuevo gobernador López Cárdenas había sido secretario de Alayola y aún no lo veían como un aliado claro. Diversos miembros del PCM secundaron también el acto de protesta contra el nuevo gobierno.

En el mitin se pidió la desaparición de poderes. Pero pasaron de las declaraciones. Los oradores invitaron a las masas reunidas a -tomar la "Casa del Pueblo", que era la sede del Partido Socialista del Sureste. Esto sí era una seria provocación. Los "socialistas" se preparaban para recuperar su local. En el interior de la "Casa del Pueblo" se discutió la propuesta de constituirse en un soviet permanente de obreros y campesinos. Cuenta El.Diario de Yucatán del 12 de octubre de 1935, que se cantó La Internacional y se extendió un amplio lienzo que ostentaba la hoz y el martillo.

Los lideres de las federaciones blancas se empezaron a retirar. Al parecer la escaramuza era inminente. Los miembros del PCM, ante la retirada de los otros líderes, aconsejaron a sus contingentes a que se retiraran también. La operación, conocida entonces como "operación muertitos", habia fracasado. Las alianzas entre la FSI, el PCM en Yucatán, el jefe de la zona militar Cházaro Pérez y el gobernador López Cárdenas, se harian claras y estrechas. ${ }^{25}$

La premura de los hacendados por derrocar al gobernador se hacia cada día más grande. El 7 de diciembre de 1935, a escasos dos meses de su designación como gobernador interino, López Cárdenas decretó la ampliación del ejido Tixkokob, repartiendo 2041 has sembradas de henequén el dia 19 del mismo mes. ${ }^{26}$

Nadie había repartido antes tierras sembradas de henequén en Yucatán. Además Tixkokob, situado a pocos kilómetros al oriente de Mérida, era la zona de mayor rendimiento. Esto iba muchísimo más allá de lo tolerable para los hacendados.

Pero éste no fue el único reparto hecho por López Cárdenas. El 5 de Junio de 1936 dio posesión de 535 hectáreas sembradas de henequén al pueblo de Euán; 498 hectáreas al de Ekmul; el 13 de junio, se entregaron 1317 hectáreas al pueblo de Seyé. Estos repartos los ejecutó, en persona, el propio gobernador: Además; el 4 de

24 Revista Yucatän, núm. 3, 1964.

25 Ibidem.

26 Fernando López Cárdenas, "Los Revolucionarios Contra la Revolución", México, 1938, p. 13. 
junio, sin estar él presente, se amplió el ejido de Dzidzantún en 2216 hectáreas sembradas de henequén. ${ }^{27}$

El gobernador se hacía sumamente peligroso para los hacendados; además de afectar sus intereses se hacía de un enorme respaldo popular. Las organizaciones populares seguían en ascenso. A la Ley de Arrendamiento Obligatorio de los Equipos para la Elaboración del Henequén dada por Alayola, siguió otra ley análoga relativa a los ingenios. ${ }^{28}$

La promoción del alza de los salarios mínimos que hizo el gobernador fue resentida por la burguesía yucateca. Por esos años, la situación de preguerra hizo que los precios de la fibra se incrementaran. A cada alza en el precio del henequén las Comisiones Especiales de Salarios Mínimos y la Procuraduría de la Defensa del Trabajo estipulaban un aumento de salarios. $Y$ en los mismos términos lo pagaba el Estado a sus empleados. ${ }^{29}$

El apoyo del gobernador a la Federación Sindical Independiente, encabezada por el Partido Comunista, hizo que la balanza de la justicia laboral se inclinara hacia los trabajadores. Al mismo tiempo, sostenía como director de educación del estado a un destacado comunista que impulsaba, a través de sus maestros rurales, la formación de sindicatos que eran afiliados a la misma FSı.

Estos hechos y otros más que se fueron desarrollando favorecieron el fortalecimiento de las fuerzas de izquierda al consolidarse mayores posibilidades de ataque a la burguesía yucateca.

La oligarquía yucateca auspició entonces la formación de un grupo paramilitar, admirador de Adolfo Hitler, llamado Avanzada Cívica Yucateca. López Cárdenas lo combatió resueltamente.

Al principio de su corto mandato, el gobernador contó con el respaldo del comandante de las fuerzas federales. El apoyo decidido del ejército difícultaba mucho a la burguesía local dar un golpe duro a su enemigo. Pero para mala fortuna de López Cárdenas, pronto, por motivos de salud, su aliado militar tuvo que abandonar el cargo. Lo sustituyó un general, Otero Pablos, -que se prestó maravillosamente a colaborar con las clases patronales para derrocar a su odiado gobernante.

Pero la oligarquía henequenera no era el único enemigo de López Cárdenas. Pese a sus afanes agraristas había manejado mal sus relaciones con el Banco de Crédito Agrícola y con la Delegación Agraria de Yucatán. En presencia de los campesinos y de los funcionarios del Banco había señalado que los empleados públicos no debían funcionar como patrones. Dijo a los ejidatarios que los anticipos del Banco deberían ser por lo menos iguales a los salarios de los peones de las haciendas cercanas a sus ejidos, y que, en caso de no obtenerlo, requirieran una amplia explicación. También fustigó la política del Banco al señalar que no debían acallar con soldados las justas demandas de los ejidatarios. ${ }^{30}$

Estas declaraciones del gobernador hicieron muy tensas las relaciones entre el Banco de Crédito Agrícola y el gobierno del Estado.

López Cárdenas se enfrentó entonces al ingeniero Candelario Reyes, que teniá-fama de ser honesto y francamente revoluciona-

${ }_{27}$ F. López Cárdenas, op. cit., p. 28-29.

28 Diario Oficial del Esiado de Yucatân, 6 de feb. de 1936.

24 F. López Cárdenas, op. cit., p. 84.

31) F. López Cärdènás, op. cit., p. 19. 
rio, lo cual le creó una mala imagen en las altas esferas del gobierno cardenista. El gobernador fue a pedirle al presidente de la República que cambiara a Candelario Reyes; Cárdenas accedió. El mandatario yucateco se dio a la tarea de encontrar sucesor para él Banco y la Delegación Agraria.

Pero resúltó que López Cárdenas dio nuevos motivos para dudar de su persona. Sostuvo que para no destruir la hacienda henequenera como fuente de empleo en el campo yucateco, debía ampliarse la pequeña propiedad henequenera a 300 hectáreas y no a 150 como el gabinete cardenista había determinado. En su libro "Los Revolucionarios contra la Revolución" señala:

...habiendo expuesto mis anteriores puntos de vista al Presidente y a las demás personas que por parte del Gobierno Federal iban a intervenir en las juntas, me hice sospechoso de estar al servicio de los latifundistas. Recuerdo algunas de las palabras del Presidente de la República en ese sentido: ya basta de decir estamos viendo, estamos observando, estamos estudiando; ya me cansé de que todo se arregle por los henequeneros con cheques para los gobernadores. ${ }^{31}$

López Cárdenas conoció al ingeniero Florencio Palomo Valencia que había publicado dos folletos sobre la cuestión henequenera: "La Deuda Agraria de México y algunos datos sobre Ejidos" y "Los Ejidos de Yucatán y el Henequén". El personaje le pareció enterado y de credo agrarista.

Hacia el final del periodo de López Cárdenas, Palomo asumió el cargo de delegado del Departamento Agrario en Yucatán y quedó al frente de la sucursal del Banco de Crédito Agricola, en sustitución de Candelario Reyes.

El 22 de mayo de 1936, la ADIH publicó un remitido en El Diario de Yucatán en el que hacia saber su beneplácito por la designación de Palomo, causando la indignación del gobernador y del mismo Candelario Reyes, pero no redujo la confianza en el nuevo delegado. Asi se pondria de manifiesto al ser nombrado, además, representante del Ejecutivo del Estado en el Consejo de la Cooperativa de Henequeneros de Yucatán.

Los hacendados creían llegado el momento de derrocar a López Cárdenas. Sentian que el apoyo presidencial se había enfriado y. que el agravamiento de la situación local podria resultar insostentble para el gobernador. Con este razonamiento se inició una nueva ofensiva, a finales de junio de 1936, apoyándose en la movilización de los ferrocarrileros y de los choferes de taxi agrupados en el Frente Unico de Trabajadores del Volante.

López Cárdenas contaba con la lealtad de las Ligas Gremiales del PSSE, con la FSI, y con parte de la dirección del Partido Comunista y, desde luego, con el apoyo de la burocracia y de la policía estatal. Sin embargo, la Confederación de Ligas Gremiales apenas empezaba a resurgir con la dirección del líder agrarista Rogerio Chalé; no era ni remotamente posible que Chalé y sus seguidores presentaran al gobernador un frente orgánico y masivo de defensa; el ejército no lo respaldó. Para evitar derramamiento de sangre prefirió no enfrentar a la policía contra los taxistas. Al parecer, sus colaboradores cercanos lo traicionaron. La Federación Sindical In-

" F. López Cárdenas, op. cit., p. 17. 
dependiente o, mejor dicho, algunos líderes de la Federación ofrecieron organizar una manifestación para bloquear las movilizaciones de los peones acasillados y de los gremios manejados por la dirigencia de los hacendados. López Cárdenas se negó.

El Frente Unico de Trabajadores del Volante exigía que algunas líneas de camiones foráneos cambiaran sus estaciones y'sus rutas. Las demandas se presentaron con una beligerancia inusitada: bloqueos de calles, insultos al gobernador, ataques de prensa, mitines y movilizaciones en las calles. López Cárdenas pretendió salir del estado y le bloquearon los caminos.

Las colaboraciones y apoyos a los taxistas crecieron como la espuma. Los ferrocarrileros, los acasillados y diversos sindicatos de la CGT respaldaron incondicionalmente a los trabajadores del volante. En las páginas de El Diario de Yucatán aparecían furibundos ataques al gobernador. ${ }^{32}$

El general Otero Pablos, jefe de la zona militar se negó a que sus tropas intervinieran. El primero de julio entró en la Plaza de Armas, frente a palacio, un fuerte contingente de trabajadores, alrededor de 20000 almas. La policia estatal tomó posición en las azoteas de palacio. En un momento se armó la batahola. Según los hacendados, los policias empezaron a barrer con los manifestantes. Según la gente cercana al gobernador, los manifestantes dispararon sobre la policia para provocarla. Se habló entonces de que en la plaza hubo 50 cadáveres como resultado de la masacre. El licenciado López Cárdenas presentó su renuncia como gobernador interino.

Según la extra de El Diario de Yucatán de ese mismo 1 de julio, se aglomeró un numeroso contingente a las puertas del Congreso estatal para exigir el nombramiento del licenciado Enrique Aznar Mendoza como gobernador del estado.

Ese mismo dia fue investido como gobernador el ingeniero Florencio Palomo Valencia que, unos meses atrás, había regresado al estado para hacerse cargo del Departamento Agrario.

Para muchos destacados promotores de la organización popular yucateca, la caída de López Cárdenas fue un serio descalabro para el desarrollo de la reforma agraria. Todas las tareas y gestiones relacionadas con el reparto de tierras quedaron paralizadas hasta la llegada, al estado, del presidente Lázaro Cárdenas en agosto de 1937.

Rogerio Chalé le escribió una dolida carta al presidente, en la que lamentaba la caída del gobernador "...que de manera tan leal a los postulados de la revolución, y a $\mathrm{Ud}$. señor Presidente, sirvió durante su gestión". Pero citemos en extenso esta carta:

López Cárdenas fue el gobernante que entregó materialmente los ejidos en Yucatán, a pesar de estar sembrados de henequén; hizo efectiva la ocupación de las máquinas desfibradoras, para que los ejidatarios pudieran desfibrar los planteles de henequén; promovió la ocupación de las centrales azucareras, para que los pequeños colonos pudieran elaborar su azúcar. Hizo más, señor Presidente: suprimió todos los impuestos correspondientes a los trámites del Estado Civil de las personas; aquí no cuestan nada los entierros, matrimonios, divorcios, etc., y este capítulo es por lo menos una supresión de setenta mil pesos

3 F. López Cárdenas, op. cit. 
al año. Con esto deseo manifestar la buena fe y la pureza de la actuación de López Cárdenas.

Los ferrocarrileros en su afán de dominar los transportes de Yucatán y la policía, hicieron el rejuego de la gritería de los choferes, que no pasaron nunca de trescientos, para hacer caer a un gobernador que estaba en desacuerdo con los hacendados de Yucatán. En una palabra, la reacción empleó todos sus medios en contra de un hombre que jamás tuvo la más ligera claudicación y que será un honor de la Revolución la gestión absolutamente revolucionaria, honesta y limpia de López Cárdenas.

Hemos de aclarar hasta la saciedad, oportunamente que Fernando López Cárdenas no tuvo ninguna injerencia en los lamentables sucesos del 1 de julio de este año en el que perecieron campesinos acasillados, traídos por los hacendados a Mérida, con pasaje libre de los ferrocarriles. Entre dichos muertos aparecieron servidores acasillados de los hacendados Felipe G. Cantón y Lorenzo Manzanilla, señores estos que son los líderes del movimiento antiagrarista de Yucatán.

...Fraternalmente TIERRA Y LIBERTAD.-

Mérida, Yucatán, 27 de agosto de 1936. El Presidente de la Confederación de Ligas Gremiales de Obreros y Campesinos de Yucatán, P. S. del S. E. Rogerio Chale. ${ }^{33}$

Esta carta seria una de las últimas actividades de Rogerio Chalé. Cayó asesinado el 6 de septiembre de 1936. Este no fue el único asesinato de un lider agrarista después de la masacre del día 1 de julio, pero sí fue el que más hondamente conmovió las esperanzas y la organización de los campesinos yucatecos.

Chalé escribió a López Cárdenas el 19 de agosto de 1936 para decirle que los trabajadores bien intencionados sabian bien que él no era el responsable de la matanza del 1 de julio. En esa misma carta le hablaba de "nuestro buen amigo el Ing. Palomo"."34

Ante el peso de los acontecimientos el presidente Cárdenas tuvo que desprenderse de lo circunstancial para salvar lo trascendente. Tratar de sostener al gobernador López Cárdenas, que habia sido un importantísimo elemento en los avances del reparto agrario, hubiera significado un pronunciado desgaste y se hubiera convertido en un foco de distracción y de freno al reparto agrario. Su relevo sonaba del todo lógico, cuando el objetivo inmediato e impostergable era el de realizar el reparto de las tierras de las haciendas. Cárdenas había echado mano a su experiencia militar.

\section{El gobernador Palomo y los obstáculos al reparto agrario}

El ingeniero Florencio Palomo Valencia parecía el hombre más indicado para tomar las riendas del gobierno estatal en sustitución del licenciado López Cárdenas. Los distintos sectores coincidían en eso.

Para el presidente Cárdenas el cambio de gobernante reducía los plazos disponibles para realizar el reparto agrario. Recordemos que en ese entonces ya sólo faltaban 18 meses para el relevo gubernamental en Yucatán, además de que las circunstancias del país cambiaban apresuradamente, no pudiendo darse el lujo de hacer coincidir unos conflictos con otros, sin riesgo de generar una ines-

33 Fotocopia de un mecanuscrito en posesión de los autores.

34 F. López Cárdenas, op. cit. 
tabilidad incontrolable. El ingeniero Palomo Valencia habia dado la impresión de ser un profundo conocedor del campo y del problema henequenero y había desempeñado con habilidad las funciones de delegado del Departamento Agrario y de gerente del Banco de Crédito Agrícola en el estado. A diferencia del licenciado López Cárdenas, no contaba con la animadversión de los hacendados y guardaba buenas relaciones con los dirigentes comunistas, tanto de Yucatán como del país.

Para los hacendados, la designación del ingeniero Palomo Valencia les caía de perlas. Además del triunfo que les había representado la salida de López Cárdenas, que había dado muestras más que palpables de ser un enemigo irreductible, la transición de mando les daba un margen de tiempo para rehacer sus presiones. Y qué mejor que intentarlas de nueva cuenta teniendo en la gubernatura a una persona conciliadora. Pero más que eso, el ingeniero Palomo habia puesto en práctica una política de acercamiento a los hacendados que hizo pensar al propio López Cárdenas que había tenido mucho que ver en su derrocamiento. ${ }^{35}$

- Finalmente, los dirigentes populares sentían que con el desplazamiento de López Cárdenas habian ganado una mayor autonomía política. Palomo Valencia parecía un revolucionario a carta cabal, hábil negociador, que respetaría algunas posiciones que detentaban reconocidos izquierdistas y colaboradores del movimiento popular -como era el caso de El Diario del Sureste y de la Dirección Federal de Educación.

Para ese entonces la FSI, el PCM y la Confederación de Ligas Gremiales, además de otras organizaciones populares, habían integrado la Alianza Popular Yucateca, como la mejor manera de organizarse ante Ia inminencia del reparto agrario. Pues bien, la Alianza Popular se declaró abiertamente a favor del recién nombrado gobernante, promoviendo una tumultuaria manifestación de apoyo.

El presidente Cárdenas tuvo especial cuidado en dar a conocer el gran apoyo y el reconocimiento que le dispensaba al gobernador Palomo; y éste no perdía ocasión de reafirmarlo y de hacerse pasar como un ferviente admirador de la persona y la obra del presidente.

El gobernador sostuvo varias entrevistas con el general Cárdenas durante el año de 1937. A fines de abril dio respuesta a la carta abierta del célebre don Luis Cabrera, viejo carrancista, opuesto al reparto de los henequenales. Palomo Valencia polemizó con el afamado revolucionario, señalando que la reforma agraria no había hecho aumentar el precio de la fibra; que los ingresos de los productores de henequén no habían sido afectados por el nuevo impuesto de 2 centavos más por kilo de fibra, decretado con fines de utilidad social, ya que simplemente reemplazaban a los 2 centavos que desde hacía varios años se venía reduciendo el precio de la fibra con objeto de amortizar la vieja deuda, de varios millones de pesos, que los productores tenían contratada con el Banco de México. También afirmaba el gobernador que su administración tenía el afán de colaborar con la obra de la recons-

${ }^{35}$ F. Lopez Cárdenas, op. cit. y Humberto Lara y Lara, "Sobre la Trayectoria de la Reforma Agraria en Yucatán", Mérida, Ed. Zamná, 1949. 
trucción nacional con sus propios fondos, para realizar una distribución mejor de los beneficios de la industria henequenera, "lejos de verse afectada por la transformación en el régimen de la propiedad de la tierra, se verá favorecida con la intervención de los trabajadores como productores autónomos". 36

Sin embargo, el gobernador Palomo se cuidó de no atacar a la burguesía yucateca. Su discurso cuando se referia al capital y a los capitalistas era en abstracto y de manera poco comprometida. El Diario del Sureste, que era desde 1931 el diario oficioso del gobierno yucateco, dejó de agredir a la oligarquía, desde el 10. de julio de 1936, en que fue derrocado el gobernador López Cárdenas y subió al poder Palomo. A cambio de ello, los hacendados dejaron de criticar al gobierno y cambiaron su actitud beligerante para buscar el entendimiento con el nuevo gobernante.

Muy pronto verían los frutos de esta actividad valiéndose de la relación tan estrecha que mantenía Hernando Ancona y Ancona, principal dirigente de la $\mathrm{ADIH}$, con el gobernador Palomo. Por influencias del gobernador, Hernando Ancona seria nombrado gerente de la Cooperativa de Henequeneros de Yucatán, institución que seguia manejando la producción y comercialización del henequén.

El 24 de julio, a unos cuantos días de haber sido nombrado gobernador interino, el ingeniero Palomo Valencia convocó a una junta en su despacho en la que rectificó la dotación de tierras que el 4 de junio anterior había sido acordada para el ejido de Dzidzantún, afectando terrenos de la hacienda San Francisco Manzanilla. Esta rectificación beneficiaba a Lorenzo Manzanilla, poderoso terrateniente que estuviera involucrado en el asesinato del líder socialista Felipe Carrillo Puerto. ${ }^{37}$

Estas decisiones propiciaron la indignación de los dirigentes populares que, desde luego, hicieron llegar sus quejas a la administración federal. En poco tiempo pudieron comprobar que Palomo Valencia tenía una gran afinidad ideológica con los hacendados y que, cuidándose de guardar las apariencias, haría todo lo posible por retrasar y negociar los términos del reparto agrario.

El mismo Palomo Valencia, pocos años después, durante la presidencia de Avila Camacho, atacaría la reforma agraria henequenera, de la cual él mismo fue actor principalísimo. En su folleto titulado "Desamortización de Ejidos 'Ejidos Gratuitos' para los Campesinos", publicado en 1945, afirma que a los campesinos ejidatarios se les ha considerado menores de edad y que esta "minoridad ciudadana" debía eliminarse dándoles el derecho de comprar y vender sus parcelas, sin que se les autorice a sobrepasar el limite de la propiedad privada. Señala que el reparto ha sido "antieconómico":

...y por tanto es deseable que cada ejidatario posea mayor existencia de terrenos, permitiéndose para ello se realice de manera voluntaria, libre y natural una selección entre los más aptos, aún cuando el número de ejidatarios de esa región disminuya...

3t El Diario del Sirreste, 26 de abril de 1936.

37 F. López Cárdenas, op. cit. y El eco revolucionario, México, D. F., 17 de abril de 1937, Humberto Lara y Lara, op. cit.

${ }^{38}$ F. Palomo Valencia, "Desamortización del Ejido 'Ejidos Gratuitos' para los Campesinos", México, 1945, p. 14. 
Esto de ninguna manera lo hubiera dicho en público Palomo cuando era gobernador. López Cárdenas se atrevió a decir que se dejaran 300 hectáreas a los hacendados y eso le valió una seria reprobación del gabinete presidencial. El ingeniero Florencio $\mathrm{Pa}$ lomo Valencia, en cambio, era un zorro político. Sabía que el gobierno local estaba amarrado a los designios del poder federal. Por eso pudo salir de la gubernatura nombrando a su sucesor y convirtiéndose en senador de la República.

Sin embargo, en 1937, el aparato motor de la reforma era el gobierno federal y el gobierno local no tenía más alternativa que plegarse a los dictámenes del centro. La oligarquía yucateca, pese a sus planes y a sus temerarios movimientos políticos, tuvo que aceptarlo. El Partido Socialista y el Partido Comunista apoyaron decididamente los movimientos del reparto cardenista.

Palomo Valencia se adaptaba a las circunstancias. Su política. parecía consistir en atender sólo aquellas cuestiones que amenazaban desbordarlo. Las cordiales relaciones que sostenía con los distintos sectores eran una mera apariencia, se había ido incubando un descontento generalizado por la falta de decisiones.

Los hacendados se desesperaban ante la ausencia de hechos concretos, habiendo quienes lo consideraran demasiado tolerante.

A mediados de 1937 Palomo Valencia se vio abrumado por los problemas que había ido dejando crecer. Un grupo de hacendados trató de adelantar la selección del candidato a la próxima gubernatura, con el afán de posponer una vez más la realización del reparto de tierras. Para ello se valieron de Gualberto Carrillo Puerto, senador de la República, que contaba con la simpatía del presidente Cárdenas y con la decidida animadversión de Palomo Valencia. Gualberto Carrillo, como ya hemos dicho antes, era un oportunista que se había valido del prestigio de su apellido para seguir medrando en la política, como instrumento de un grupo de hacendados.

El 1 de julio de 1937, 15 senadores enviaron un telegrama a Palomo para decirle que habian estado recibiendo quejas de los pueblos de Valladolid, Cuzamá, Yaxcabá, Hoctún y Cansahcab, de los simpatizantes del senador Gualberto Carrillo que habian sido atropellados y que las autoridades les habían impedido ejercer sus derechos cívicos. ${ }^{39}$

La prensa nacional y la local se hicieron eco de estos problemas. Palomo Valencia no podía sentirse seguro con las cuestiones que parecian multiplicarse. Pero el general Cárdenas necesitaba estabilidad para que el aparato del Estado nacional pudiera actuar con eficiencia. El reparto de los henequenales no iba a esperar más. La acción agraria concentraba la atención y los otros asuntos tendían a verse menos. La escena política estaba convulsionada. El gobernador iba perdiendo el apoyo incondicional de su propio aparato de gobierno. Sin embargo, tenia asegurado el respaldo del centro. Palomo Valencia, en estas condiciones, no tuvo más alternativa que respaldar la política agraria del presidente de la República.

El gobierno del Estado tuvo que refrendar su vocación agrarista y su apego al presidente. Era claro que Palomo Valencia presentaba esta carta agrarista como lo fundamental de su administra-

${ }^{39}$ AGE Poder Ejecutivo 1936-37, vol. 2, caja 1041. 
ción ante las instancias del poder federal y ante el Partido Nacional Revolucionario.

Pero es interesante ver cómo interpretaba Palomo su compromiso agrarista. El 23 de julio de 1937, en respuesta a una carta de Silvano Barba Garcia, presidente del Comité Ejecutivo del PNR, en la que le habia pedido informara sobre los postulados del Plan Sexenal que había cumplido el gobierno de Yucatán, Palomo alababa a Cárdenas y explicaba que habia presentado dos iniciativas de ley para asegurar la riqueza henequenera estimulando las siembras del agave. "La esencia de dichas leyes no radica en quién ha de poseer esa riqueza, sino en que esa riqueza subsista y se fomente; tal es la médula de la Ley de Garantía de Nuevos Plantíos de Henequén, expedida el 30 de diciembre de 1936." También hablaba de otra ley que destinaba parte del impuesto del henequén al cultivo de los henequenales. Señalaba que se habian comprado dos haciendas, Dzununcán y San Ignacio, para que los campesinos trabajaran en cooperativas. Hablaba de la construcción de cinco carreteras. Explicaba que se habían destinado 1200000 pesos para ayuda económica a los municipios, traslado de trabajadores a otras regiones del estado en busca de mejores condiciones de vida, crédito a trabajadores para actividades productivas, escuela de artes y oficios, Academia de la Lengua Maya, sostenimiento de hospitales y brigadas sanitarias, procuraduria e internados mayas, becas para hijos de los trabajadores. ${ }^{40}$

Es claro que el poder ejecutivo estatal, como entidad política estaba inmerso en un juego de fuerzas que no le permitian autonomía. Le brindaban, eso sí, elementos para un ejercicio del poder siempre limitado y lleno de condicionantes. Las fuerzas populares integradas al aparato del estado local, y en otro tiempo dirigidas y dominadas por los gobernadores "socialistas" de Yucatán, en 1936-37 estaban sensiblemente apegadas a la decisión del reparto agrario.

Las Ligas Gremiales no sólo eran el sustento del aparato político del estado yucateco, también estaban integradas orgánicamente al Partido Nacional Revolucionario, que se apegaba a las politicas del presidente Cárdenas.

El respaldo al gobernador del Partido Comunista y sus organizaciones sindicales, no era autónomo. Obedecía a las consignas internacionales del Kremlim de "unidad a toda costa frente al fascismo". Y esto, en el contexto político de aquellos años, significaba apoyo al aparato de hegemonia cardenista, aunque en el PCM de Yucatán había una fuerte corriente hostil al gobernador $\mathrm{Pa}$ lomo Valencia. Esta corriente había estado encabezando un movimiento de los burócratas del estado en contra del ejecutivo estatal. Además esta misma corriente tenía una gran influencia en la Federación Sindical Independiente.

Palomo Valencia, o cualquiera que hubiera estado en su puesto, no tenía fácil el ejercicio del poder. Pero Lázaro Cárdenas necesitaba estabilidad en el ejecutivo local para poder realizar la ampliación de los ejidos henequeneros sobre las tierras sembradas de henequén de las haciendas. Por eso y por sobre todas las evidencias en su contra, Palomo Valencia seguía gozando del total apoyo presidencial.

40 AGE Poder Ejecutivo 1936-37, vol. 2, caja 1041. 
Todavía el 9 de agosto, un día después de haberse iniciado el reparto de los henequenales, el general Cárdenas ensalzaba la labor de Palomo Valencia: “...sin los estudios, conocimiento y cooperación del Ing. Palomo Valencia, el gobierno federal no hubiera abordado tan felizmente el problema ejidal". ${ }^{41}$

$Y$ era lógico que así sucediera. El presidente tenía que encontrar la manera de comprometer al gobernador del estado. A él le toca- ría completar y sostener el reparto agrario.

Finalmente, el 8 de agosto, el presidente Cárdenas daría a conocer los términos en que se realizaría el reparto de los henequenales. Los doce puntos resolutivos del Acuerdo son una evidente manifestación de la existencia de un proyecto integral para la zona henequenera, radicalmente distinto al que habian sostenido los hacendados durante casi un siglo. Conviene conocer en detalle el Acuerdo que diera a conocer el presidente Cárdenas en el mensaje que dirigiera al pueblo yucateco ese día. ${ }^{42}$

1. Las autoridades agrarias procederán a tramitar y resolver los expedientes de restitución, dotación y ampliación de ejidos relativos a los núcleos de población ubicados en la zona henequenera del Estado de Yucatán.

2. Los peones o trabajadores de las haciendas a las que este Acuerdo se refiere, tienen derecho a ser considerados, para los efectos del mismo, en los Censos Agrarios respectivos.

3. Se respetará como pequeña propiedad agricola en explotación, la superficie sembrada de henequén que no exceda de 150 hectáreas, más la extensión sin henequén, hasta completar la pequeña propiedad en terrenos no irrigados y pastales que señala el Código Agrario.

4. La extensión de henequenales que se entreguen a los núcleos de población, como dotación o como ampliación de ejidos, se fijará de acuerdo con el número de sujetos de derecho agrario y un coeficiente individual de 4 hectáreas por capacitado. Cuando los poblados ya posean henequenales, la extensión de terrenos incultos que formará parte de cada ejido, se formará de acuerdo con los artículos 39,40 y 49 del Código Agrario.

5 . A fin de que los ejidos constituyan unidades agrícolas industriales de producción permanente, se procederá a la adquisición de las extensiones que conserven las fincas afectadas, y de los equipos industriales existentes en ellas, como edificios, maquinaria, vias, semovientes y, en general, todos los medios productivos que los integren, en cuanto sea necesario para el beneficio industrial del henequén que se produzca. Estas adquisiciones serán hechas por conducto de la Secretaría de Hacienda y Crédito Público, y los bienes adquiridos serán de la propiedad común de todos los ejidatarios. El Gobierno del Estado, si lo desea, contribuirá a tales adquisiciones.

6. Teniendo en cuenta la naturaleza del cultivo del henequén y la necesidad de su industrialización para la mejor explotación económica de los ejidos henequeneros, ésta se organizará en forma colectiva.

7. El Gobierno Federal, por conducto de la Secretaría de Hacienda y Crédito Público, facilitará las cantidades que sean necesarias: a) Para que el Banco Nacional de Crédito Ejidal pueda conceder los créditos que los ejidatarios necesiten para la explotación agricola industrial de los ejidos; en la inteligencia de que no se cobrarán intereses a los campesinos que inicien sus actividades productivas, mientras éstas no proporcionen los rendimientos que permitan pagarlos, y de que el tipo de

+1 El Diario del Sureste, 10 de agosto de 1937. 1978.

Lázaro Cárdenas. "Mensaje al Pueblo de Yucatán": Mérida, ISSTEY, agosto, 
interés y los plazos de los préstamos se fijarán siempre teniendo en cuenta la capacidad económica real de los interesados. b) Para que el Banco Nacional de Crédito Agricola opere con los agricultores que tengan el carácter de pequeños propietarios o que lo adquieran por virtud de las afectaciones ejidales, siempre que así lo soliciten en los términos de la Ley de Crédito Agrícola en vigor. c) Para que el Banco Nacional Obrero de Fomento Industrial, de acuerdo con su ley constitutiva, refaccione a los productores y obreros organizados, por lo que se refiere a las actividades de beneficio industrial del henequén, cuando las inversiones realizadas por las anteriores instituciones no sean suficientes para las necesidades económicas de la industria henequenera.

8. Se procederá a establecer, de acuerdo con el Gobierno del Estado de Yucatán, los organismos necesarios para el fomento y desarrollo de la industria henequenera, y para la venta del henequén que se produzca. En ellos tendrán intervención los gobiernos Federal y local, y se concederá a los productores una representación proporcional al interés que tengan en la misma industria.

9. La Secretaría de Agricultura y Fomento llevará a cabo la creación de un Instituto Agrícola Henequenero, en el lugar que considere más conveniente, dentro de la propia zona.

10. La Secretaria de la Economía Nacional ordenará se continúen los estudios de laboratorio para el aprovechamiento de los desperdicios del henequén, así como sobre cordelería moderna, para el establecimiento de factorias.

11. La Secretaría de Comunicaciones y Obras Públicas procederá, de acuerdo con el Gobierno del Estado, a la apertura de la red de comunicaciones que exige el desarrollo de la industria henequenera.

12. El Departamento Agrario prestará una atención inmediata a las necesidades sociales de los campesinos, a quienes otorgará la ayuda más eficaz para satisfacerlas. La Secretaría de Educación Pública organizará los servicios educacionales mejorando las escuelas existentes, y creando las que se consideren necesarias; el Departamento de Salubridad Pública establecerá, desde luego, el Servicio Sanitario Ejidal; los Departamentos de Asistencia Social Infantil, de Asuntos Indígenas y de Educación Física, iniciarán, asimismo, las actividades que deben realizarse en beneficio de la población campesina de Yucatán.

El Presidente de la República, Lázaro Cárdenas.

El mismo presidente de la República, general Lázaro Cárdenas, ejecutó la primera asignación de tierras afectadas a una hacienda henequenera. La situación era sumamente tensa. Se habían concentrado fuerzas militares especiales. El presidente personalmente conocía y evaluaba las acciones cumplidas. Un día después de haber llegado a Yucatán se trasladó a la hacienda Temozon -la misma en que fueran asesinados Ignacio Mena y Adalberto Sosa el 19 de enero de 1936- a fin de expropiar los henequenales. Ahí se indemnizó a las viudas de los dirigentes asesinados, se puso en marcha un molino de nixtamal y se organizó una cooperativa de consumo.

En pleno proceso de reparto de los henequenales el 17 de agosto, los burócratas dieron a conocer su pliego petitorio. Exigian el reconocimiento de su organización, llamada Sindicato Unico de Trabajadores al Servicio del Estado (SUTSE) y también que se promulgara una Ley de Servicio Civil, en beneficio de los servidores del estado, similar a la expedida por el C. presidente de la República, general Lázaro Cárdenas. Demandaban la elaboración y 
aprobación de un escalafón riguroso, estipulación clara de descanso y vacaciones, jubilación; que sólo pudiera separarse a un empleado por causas verdaderamente justificadas. Solicitaban también una "casa del trabajador al servicio del estado" con biblioteca y dispensario. ${ }^{43}$

Veintiséis organizaciones políticas y sindicales pidieron al gobernador concediera el estatuto. Entre las organizaciones firmantes se encontraban la Alianza Popular Yucateca, que agrupaba a casi todas las organizaciones de izquierda en el estado, el Partido Comunista, la Confederación de Ligas Gremiales PSSE, el Sindicato de Ferrocarrileros, las Juventudes Socialistas y la Federación Sindical Independiente. ${ }^{44}$

Palomo se resistía a conceder el estatuto juridico. Sabía que esto suponía entregarle poder al SUTSE y con ello, a los sectores más radicales del $\mathrm{PCM}$, que formaban parte de la dirección del sindicato.

Entre las dotaciones dadas a conocer el 8 de agosto aparecia, nuevamente, el ejido de Dzidzantún, el mismo que había recibido una resolución, a su favor, el 4 de junio de 1936, bajo el gobierno de López Cárdenas, y que un mes y medio después cuando asumiera el mando Palomo Valencia, sufrió la rectificación. La resolución definitiva sólo reconocería 1912 has sembradas de henequén. de las 2216 has de que se le habia dotado originalmente. ${ }^{45}$

Así, entre presiones y forcejeos, en un clima de asonada, con $\mathrm{Pa}$ lomo y hacendados, se hizo el reparto de tierras en Yucatán. La Revolución mexicana había saldado una cuenta pendiente...

+3 AGE Poder Ejecutivo 1936-37, vol. 2, caja 1041.

+t Ibide'm.

4s Eric Villanueva Mukul, "Asi Tomamos las Tierras", Mérida, Ed. Maldonado, 1984. 